音声言語医学 $57: 261-271,2016$

原 著

\title{
典型発達児のナラティブのストーリーの構造と内容の発達
}

\author{
小坂 美鶴
}

要 約 : ナラティブは言語, 認知, 社会性の能力を含んでいる. 本研究では異なる材料と課 題を用いて典型発達児のストーリーの構造と内容の発達に関して横断的な検討を行った. 4 ： 01〜 6: 11 の典型発達児 118 名を対象として“Frog, Where Are You?”と“ぞうさん故郷に 帰る”のストーリーを用いて, 自発話課題と再生課題を行った。分析は材料㧍よび課題による 差異を比較した。

その結果, ナラティブはすべての年齢で課題や材料によらず，ストーリーの長さや語彙数, 統語に扔いて同一個人内での高い相関があった。 また, 両材料, 両課題ともに年齢の増加とと もに自立語数が有意に増加し, さらに内容も豊かになった。年齢群ごとの比較では 4 歳と 5 歳 以上で有意な差異があり，4歳児においては十分なストーリーの内容を再生し, 物語ることは 難しいことが示された。しかし，5歳以上では徐々に材料による差異が明確になり，6歳では 有意に材料間の差異があった。

言語の形式と内容は一体となり発達し，5歳以降でのナラティブの発達が認められた。課題 や材料によらず, 個々の産出能力は一貫していた。 典型発達児のナラティブの発達の標準的な 結果を示し，評価ツールとして有用であることを示すことができた.

索引用語: 典型発達児, ナラティブの発達, ストーリーの材料と課題, 物語の構造と内容

\section{Narrative Development of Contents and Structures in Story Telling}

\section{Mitsuru Kosaka}

\begin{abstract}
This study investigated development of narrative abilities through contents and structures in telling stories. The participants were 118 typically developing children (4: 01-6: 11). Two stories and two tasks were prepared. Each child was presented with 10 pages of a wordless picture book extracted from a story entitled, “Frog, Where Are You?” (Mayer, 1969). The other was an original picture story entitled, "A little elephant goes back home with his mother." The children conducted spontaneous speech and retelling tasks. All narratives were recorded with an IC recorder and transcribed for analysis.

The results showed that the stories produced by the 4-year-old group contained fewer words and poorer content compared to the over-5-year-old group in both materials and tasks. There were some individual differences in relation to story lengths within the same age group. These findings suggest that children develop contents and structures in telling stories at the same time. Narrative skills have no relation to the materials and tasks. As a
\end{abstract}

川崎医療福祉大学医療技術学部感覚矯正学科言語聴覚専攻：干701-0193 岡山県倉敷市松島 288

Division of Speech Language Pathology and Audiology, Department of Sensory Science, Kawasaki University of Medical Welfare: 288, Matsushima, Kurashiki, Okayama 701-0193, Japan

2015 年 1 月 13 日受稿 2015 年 10 月 28 日受理 
group, children from 5 years old and above produce stories rich in structures and contents. The results indicated different narrative skills for each age in preschool.

Key words: typically developing children, narrative development, materials and tasks in telling stories, narrative structure and content

\section{はじめに}

子どもが言語を獲得し，対人関係的文脈のなかでコ ミュニケーションが可能になり始めると次にテクスト 形成的機能の発達により, 適切な表現形式が必要に なってくる，文以上の単位である談話レベルでは，文 と文の連接（結束性要素）が談話テクストの整合性と の関連性において重要となる。一つ一つの文が的確で あったとしても，文と文が結合した場合に意味的に的 確になるかどうかは結束性要素の影響が大きい。ナラ ティブの理解や産出は, 聞き手側の態度やどのように 話しどのように導き出すか, 内容の複雑さや構造的な 複雑さ，内容のまとまりや形式的なまとまりによって 個人差が大きい.

子どもは 5 歳までには多くの語彙と形態統語論的な 構造を獲得する1,2)。しかし，言語知識の獲得とその 使用は学童期を経て成人まで続く。ナラティブを産出 するためには原因や意図，空間，役割の関係の知識を もたなければならない。ナラティブの発達は言語，認 知，社会性の能力のような多側面を含む．英語圈での 談話研究は他の言語発達研究の領域と同様に質量とも に活発な研究が行われている。 なかでも物語を語るこ とに関して 'dinner table' のストーリー3) や Mayer ${ }^{4)}$ の字のない絵本 “Frog, Where Are You?” などの材 料を用いた研究がある ${ }^{5-7)}$. いずれも単に言語的側面 ばかりではなく，異なった文脈や文化や時間を見るこ とができるッールとして研究されてきた，ナラティブ は語彙や統語, 使用などの言語能力の発達, さらに連 続した出来事を構成し，記憶しておくこと，話し手と 聞き手といった対人関係の能力を必要とするものであ り，登場人物の客観的な評価や関係性の推測を物語の 内外からの情報を用いて想像し，物語を創造すること である8

また，近年増加傾向にある自閉症スペクトラム（以 下 ASD）は言語能力と関連性の深い社会的推論の障 害がその特性であり，意味論・語用論の障害を中心と している，そのなかでも言語形式（音韻や統語など） の障害を合併しないタイプにおいては，他の言語学的 領域では問題を明確にすることができないことが多
く, 欧米圈では ASD のナラティブの研究が増加して きている ${ }^{9,10)}$ ，それに対してわが国では談話に関する 研究および発達的順序や正常な偏りや変化に関しての 示唆を与える文献は少なく, 分析方法についてもいま だ確立されていないのが現状である。わが国の談話の 発達研究では産出されたテクストそのものを分析した 研究は少なく, 学齢児の作文に関しての分析 ${ }^{11}$, 談話 の長さや様式についての分析 ${ }^{12,13)}$ などいくつかの報告 にとどまっている。ナラティブの産出は単語や文に比 べ典型発達においても個人差が大きくなると考えられ る。日本語でのナラティブ研究のための基礎デー夕が 少なく, ASD 児や他の発達障害児のナラティブの産 出の発達を比較研究するためにも典型発達児を対象と した研究には重要な意義がある。

海外での研究から幼児では談話内容や言語構造は経 験を一般的出来事表象 (General Event Representation: GER）によって影響を受け，幼児の GER は一般 的なスクリプトモデルのなかで特徵づけられる ${ }^{14)}$. GER とは毎日の同じような出来事の記憶が抽象化さ れ知識として表象化されることである。談話は子ども の体験に依存し, さらに認知・言語面の能力の差異を 反映するのであり，そのためナラティブの産出はそれ ぞれの子どもの体験の違いを含め, 認知や言語の能力 の個人差が大きく影響する，それぞれの国の文化が異 なることもあり，ナラティブに用いた材料によっても 差異が大きいと考えられ，わが国の文化を反映した材 料の検討は重要な要因である.

そこで本研究では海外で行われているナラティブ研 究で使用されている材料である “Frog, Where Are You?”（以下 Frog）とわが国の子どもたちの早期語 彙獲得語であるぞうを主人公としたオリジナルのス トーリーである“ぞうさん故郷に帰る”（以下ぞうさん） を比較して, 典型発達児のナラティブの横断的な検討 ならびに材料による差異を検討した。

\section{方法}

\section{1. 対象}

絵画語い発達検査（以下 PVT-R) ${ }^{15)}$ において語い年 齢（以下 VA） 3 歳以上で発達障害の診断がなく，保 
育上支障がない保育園児 118 名 $(4 ： 01 \sim 6 ： 11$ ，男児 75 名，女児 43 名）とした。な打対象児は年齢ごとに 4 歳児, 5 歳児, 6 歳児と分け, さらに対象児のうち 材料の違いでFrog の自発話課題とぞうさんの再生課 題を行った $\mathrm{A}$ 群とぞうさんの自発話課題とFrog の再 生課題を行った B 群に分けた. A 群の 74 名の対象児 は 4 歳児群 29 名の生活年齢（以下 CA）の平均は 4: 05 (男児 10 名, 女児 19 名), 5 歳児 23 名 (平均 CA 5: 05 , 男児 16 名, 女児 7 名), 6 歳児 22 名（平均 CA 6: 03 , 男児 12 名, 女児 10 名）であった. B 群の 44 名 の対象児は 4 歳児 14 名 (平均 CA 4:06, 男児 7 名, 女児 7 名), 5 歳児 15 名 (平均 CA $5: 05$, 男児 10 名, 女児 5 名), 6 歳児 15 名 (平均 CA $6: 05$, 男児 11 名, 女児 4 名）であった. A 群 74 名の CA と VA との相 関は $\mathrm{r}=0.70(\mathrm{p}<.01)$ であり, B 群 44 名の CA と $\mathrm{VA}$ との相関は $\mathrm{r}=0.59(\mathrm{p}<.01)$ であり，いずれも高 い相関が認められた。それぞれの対象群の VA は A 群 4 歳児群の平均 VA 3:08 (SD 7 力月), 5 歳児群 の平均 VA 4:11 (SD 11 力月), 6 歳児群の平均 VA 5: 06(SD 15 カ月)であった. B 群の 4 歳群の平均 VA 3: 09 ( $\mathrm{SD} 7$ 力月), 5 歳览群の平均 VA 4:10（SD 12 力月), 6 歳巟群の平均 VA 5:07 (SD 10 カ月) で あった

\section{2. 手続き}

材料はFrog とぞうさんの 10 シーンの色つきの系 列絵を用い, A 群 74 名と B 群 44 名を比較した。なお, Frogについては物語構造を壊さないように 24 シーン のオリジナルを 10 シーンのストーリーに短縮し，さ らに色つきの絵とした。自発話課題では両材料ともに 紙芝居形式で提示した系列絵 10 シーンをすべて見せ た後に再度 1 枚ずつ提示しながらその話を話してもら うよう教示し, 再び1枚ずつ提示し絵を見ながら話し てもらった，また，再生課題では両材料ともに系列絵 を 1 枚ずつ見せながら，験者がその内容を話して聞か せ，その後，絵を見せずに話してもらった，発話は ICレコーダーに録音し，すべて転記し分析資料とし た. 両材料は付録 1 に示し, それぞれの材料（10枚 の絵）を設定，目的，展開，結末の物語構造に分類し た、絵に合わせたストーリー内容（18 項目）を筆者 が操作的に作成し，基準として用いた（付録 2). Frog とぞうさんのストーリーの構造は異なっていた。

\section{3 . 分析}

各被験児から得られた発話デー夕を筆者が品詞分析 を行った。 さらに, 以下の言語構造的, 内容と物語構 造の側面から分析を行い, CA と比較した。
発話の長さの発達的変化については統語発達と関連 しており, 欧米圈では Brown ${ }^{1)}$ の平均発話長（Mean Length of Utterances: MLU) という形態素単位によ る平均的な長さを指標とする場合が多い. 膠着語であ る日本語の言語獲得では文法的最小単位で獲得してい くとは考えられず, 複数の語からなる一定の文節を定 型パターンとして習得することが知られている。その ため，発話を一品詞より大きな言語単位すなわち自立 語に分節化するほうが妥当であるとされ，助詞，活用 形，接頭・接尾辞を除いてワード単位での分析を行っ ている ${ }^{16,17)}$ 。本研究では発話の長さの指標として産出 された全自立語数を用いた。言語構造からの分析では （1）ストーリーを構成している自立語数すなわち名詞 （連体詞，感動詞を含む）, 動詞，形容詞（形容動詞を 含む)，副詞，接続詞に分解した後にナラティブの長 さの指標とした，また，(2) 文レベルにおいて自立語 から除いた付属語（助詞, 助動詞, 補助動詞）の使用 を統語的指標として数量を求め, 材料, 課題ごとに比 較した.物語の内容と物語構造の分析として (3) ストー リーの内容の出現率を年齢, 材料, 課題ごとに比較し た. 基準と異なる表現方法については内容を重視し, 内容的に合っている場合はその内容が出現したとして 評価した。たとえば内容番号(1)「蛙をつかまえてき」 に対して「蛙が扔った」, 内容番号(4)「その間に蛙が 逃げた」に対して「蛙が扔らんくなった」の表現を当 てた。ささらに（4）ナラティブで使用された新しい単 語 (異なり語彙) の数量とストーリーの内容の出現数 を比較した，CA およびVA は高い相関があったため 結果は CA での比較のみとし, 横断的に検討した。 な お, 本研究はデー夕収集から分析まで筆者が行った。 実際のデータ分析を付録 3 に示した。

\section{結果}

\section{1. ナラティブに使用された語彙と統語の分析}

自立語数の年齢による变化は材料の異なる自発話課 題では Frog $(r=0.37, p<.01)$ およびぞうさん $(r=0.32$, $\mathrm{p}<.05)$ ともに年齢の増加とともに有意に自立語数は 増加した（図 1). 同様に再生課題においても Frog ( r $=0.42, \mathrm{p}<.01)$, ぞうさん $(\mathrm{r}=0.30, \mathrm{p}<.05)$ ともに 材料が違っても年齢との間で有意な相関が認められた (図 2). 自立語数はFrog とぞうさんの自発話課題と 再生課題での有意な相関 $(r=0.46, p<.01)$ が認めら れた（図 3)。また，自発話課題と再生課題での Frog とぞうさんでも有意な相関 $(\mathrm{r}=0.5, \mathrm{p}<.01)$ が認め られた（図 4$)$. 同一個人は課題（自発話と再生）や 
自立語数

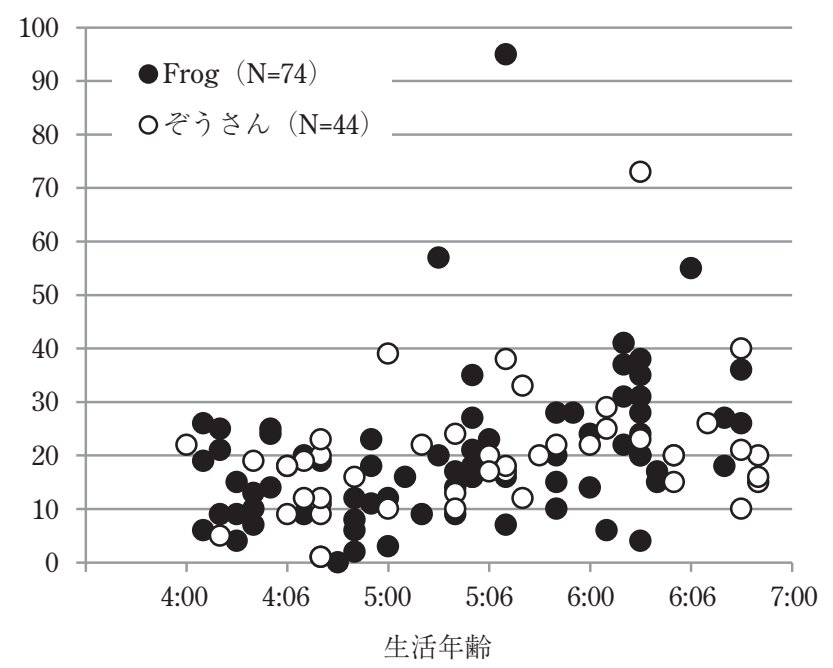

図 1 Frog とぞうさんの自発話課題における自立語数 縦軸に自立数, 横軸に生活年齢を示した.

\section{自立語数}

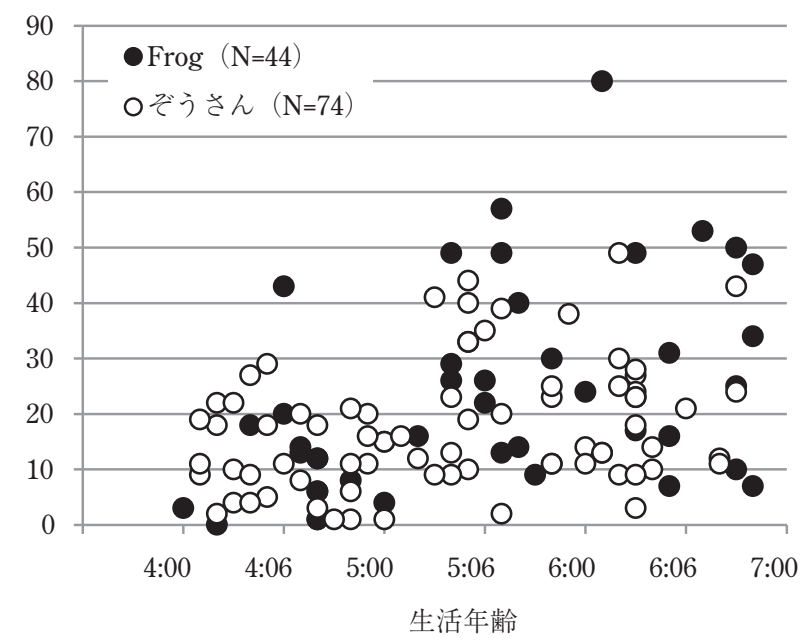

図 2 Frog とぞうさんの再生課題における自立語数 縦軸に自立数，横軸に生活年齢を示した。

材料（Frog とぞうさん）の違いによらず自立語数に 高い相関があった，また，年齢群ごとの自立語数の平 均を分散分析により比較したところそれぞれの年齢の 水準での差異が認められたため, 多重比較検定 (Fisher の最小有意差法）を行った。 4 歳児群と 5 歳児群, 4 歳児群と 6 歳児群のすべての課題で有意差 $(\mathrm{p}<.01$ 〜.05）があった．さらに 5 歳児の Frog の自発話課題 と 5 歳児のぞうさんの再生課題の有意差 $(\mathrm{p}<.05)$ が あった。さらに 6 歳児群と 5 歳児群では 6 歳児の Frog の再生課題が 5 歳児群の Frog の自発話課題よ り有意に自立語数が多く（ $\mathrm{p}<.05 ）$ ，また， 6 歳児群 のぞうさんの自発話課題が 5 歳児群の Frog の自発話
再生課題

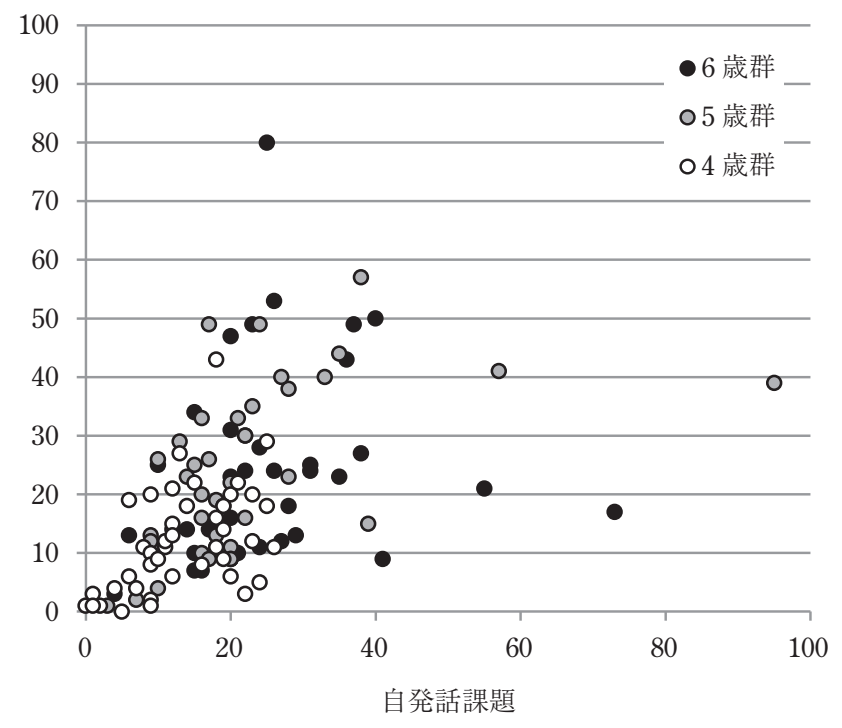

図 3 課題別（自発話課題と再生課題）の自立語数の比較 縦軸に再生課題, 横軸に自発話課題の自立数を示した.

ぞうさん

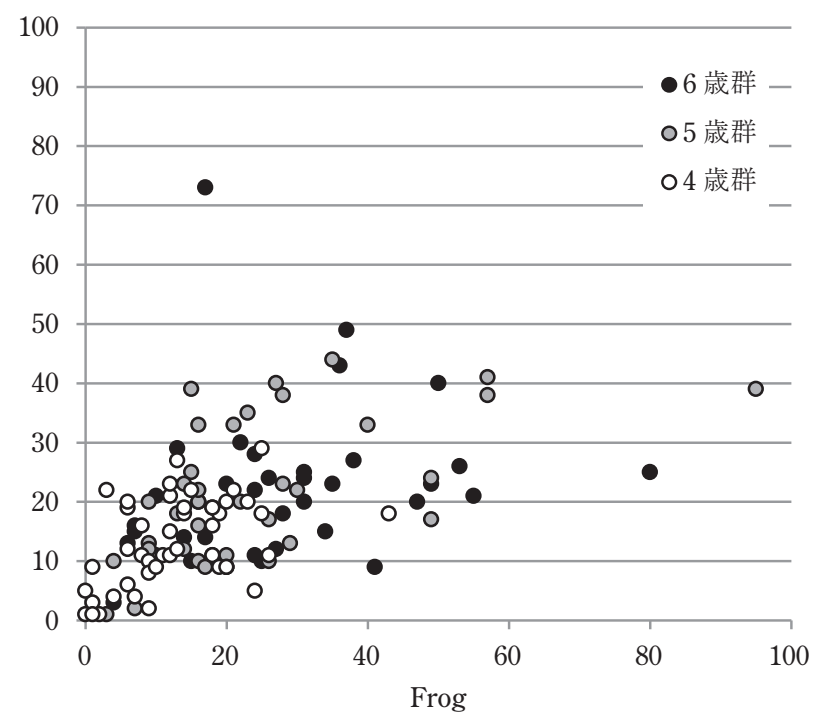

図 4 材料別（Frog とぞうさん）の自立語数の比較 縦軸にぞうさん, 横軸にFrog の自立語数を示した。

よりも有意に自立語数が多かった（ $\mathrm{p}<.01 ） （$ 図 5).

統語的指標として付属語数の数量を求めた。自立語 数と付属語数は有意な相関 $(r=0.94, \mathrm{p}<.01)$ があっ た（図 6).

\section{2. ナラティブの内容と物語構造の分析}

絵に合わせたストーリーの内容はFrog では設定(1) (2)(3)(4)(5)6), 目的 (7) 8)(9)(10(11), 展開(12)(13)(15)16), 結末 (17) 18) とっている. 各年齢群での Frog の内容の自発 話課題での出現率は 4 歳児群では対象児の $50 \%$ 以上 出現した内容はなく, 30〜 50\%で「ベッドで寝た」「二 匹の蛙がいた」「たくさんの子どもの蛙が出てきた」「蛙 
にバイバイして帰った」の 4 つの内容のみであった. 5 歳児群では $30 \%$ 以上出現した内容が 10 あり, 6 歳 児群では 13 と年齢とともに内容が増加した. 再生課 題で $30 \%$ 以上の出現は 4 歳児群で 4,5 歳児群で 10 , 6 歳代で 12 あった. 4 歳児群では内容番号(3)寝たこと, (15)(16)蛙がいたこと, 18)バイバイして帰ったことを表現

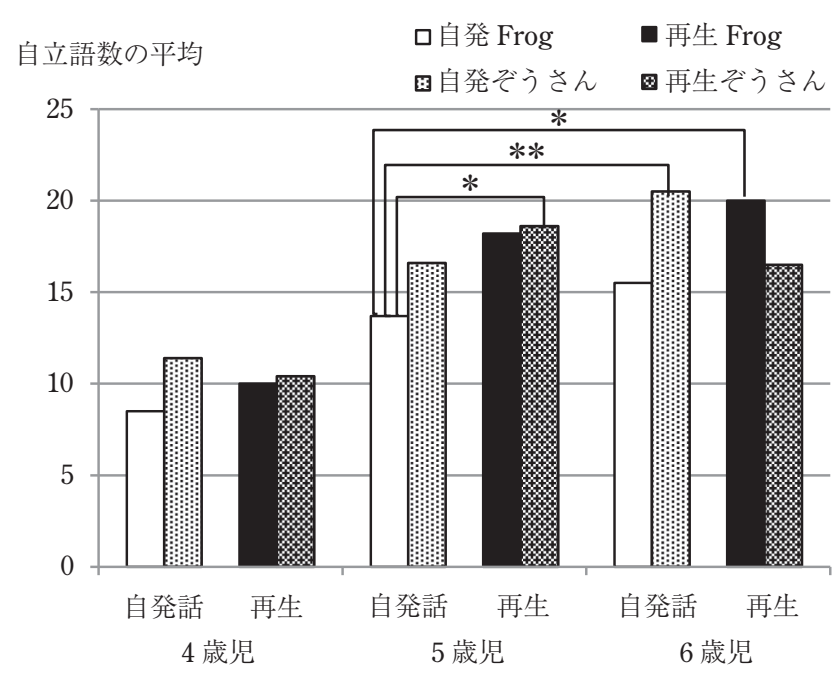

図 5 各課題および各材料の自立語数の各年齢群別の平均 4 歳群と $5 \cdot 6$ 歳群はすべての項目で有意差があったが, グラ フ上では有意差を表していない. 5 歳児群と 6 歳児群では有 意差表示を $\mathrm{p}<.01$ を**, $\mathrm{p}<.05$ を*で示した.
した． 5 歳児群以上になると 4 歳児群の内容に加え, 蛙が逃げていなくなり森に出かけ，蛙を見つけたこと といった物語構造の目的, 展開, 結末の表現が出現し た。

自発話課題と再生課題では 4 歳児群で設定部分の詳 細（蛙がいないこと）の叙述が可能になったが, ストー リーの中盤の目的, 展開などの内容が久如し, 設定と

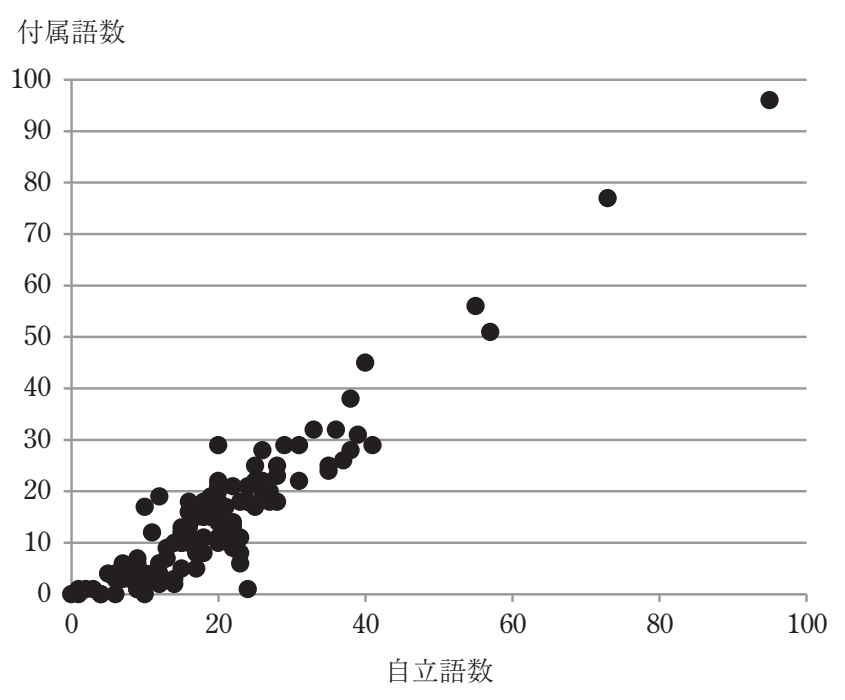

図 6 自立語数に対する付属語数

表 1 Frogのストーリーの内容

\begin{tabular}{|c|c|c|c|c|c|c|c|}
\hline \multirow{2}{*}{ 構造 } & \multirow{2}{*}{ Frog のストーリーの内容 } & \multicolumn{3}{|c|}{ 自発 } & \multicolumn{3}{|c|}{ 再生 } \\
\hline & & 4 歳 & 5 歳 & 6 歳 & 4 歳 & 5 歳 & 6 歳 \\
\hline \multirow{6}{*}{ 設定 } & (1)蛙をつかまえてきた & & & & 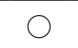 & & (0) \\
\hline & (2)蛙を犬と一緒に見ている & & 0 & 0 & & & \\
\hline & (3)ベッドで寝た & $\bigcirc$ & 0 & 0 & () & () & $\bigcirc$ \\
\hline & (4)その間に蛙が逃げた & & () & 0 & & 0 & 0 \\
\hline & (5)朝起きた & & & $\bigcirc$ & & ()) & (a) \\
\hline & (6)蛙がいない & & 0 & ()) & $\bigcirc$ & () & $\bigcirc$ \\
\hline \multirow{5}{*}{ 目的 } & (7)家の中を探した & & & & & () & O \\
\hline & 8)長靴や瓶の中を探した & & & $\bigcirc$ & & & 0 \\
\hline & 9蛙がいない & & & & & & \\
\hline & (10)外に出た & & & 0 & & & \\
\hline & 11森に向かって叫んだ & & () & $\bigcirc$ & & & \\
\hline \multirow{5}{*}{ 展開 } & 12池に落ちた & & $\bigcirc$ & $\bigcirc$ & & & \\
\hline & (13)木の陰から蛙の声が聞こえた & & $\bigcirc$ & & & () & $\bigcirc$ \\
\hline & (14木木の陰をのぞいてみた & & & $\bigcirc$ & & 0 & \\
\hline & (15)二匹の蛙がいた & $\bigcirc$ & () & 0 & & 0 & (0) \\
\hline & (16)たくさんの子どもの蛙が出てきた & $\bigcirc$ & () & () & & $\bigcirc$ & $\bigcirc$ \\
\hline \multirow{2}{*}{ 結末 } & (17)一匹もらった & & & & O & O & O \\
\hline & 18蛙にバイバイして帰った & 0 & () & (0) & & & (0) \\
\hline
\end{tabular}

対象児の $75 \%$ 以上出現した内容を○，50\%以上出現した内容を○，30\%以上出現し た内容を○で示した。 
結末のみの出現となった（表 1).

一方, ぞうさんのストーリーの構造は設定(1)(2)(3)(4), 目的(5)(6), 展開(7)(8)(10(11)(12)(13)(14, 結末(15)(16)(17)(18)となっ ている。 ぞうさんの自発話課題のストーリーの内容の 出現は 4 歳児群でも $30 \%$ 出現した内容は 9 であり, 5 歳児群は 11,6 歳児群は 13 であった。 ぞうさんの再 生課題では 4 歳児群で 5,5 歳児群で 11,6 歳児群で 8 であった。物語構造の設定部分の車にぶつかったと いうことはすべての年齢群で高頻度に出現し, 救急車 が来たこと，鼻に包帯をまいてもらったこと，けがが 治ったこと，お母さんが来たこと，木の下にある家の ことなど物語構造の設定, 目的, 展開, 結末について 表現することが可能であった，絵からの叙述課題の自 発話課題に比較し, 再生課題では 4 歳児群と 6 歳児群 で内容が減少した (表 2)。

両材料ともに 4 歳児群は内容の出現率は少なく, 5 歳児，6歳児群で増加した。 また， 4 歳児の自発話に おいて Frogよりもぞうさんのストーリーのほうが多 い傾向があった，自発話と再生では Frog では内容の 出現率に大きな変化はなかったが, ぞうさんでは自発 話のほうが出現する内容が多い傾向があった４歳児 群ではFrog で目的や展開が欠如する傾向があり, 設 定と結末のみの構造であった。 5 歳児, 6 歳児群では
すべての構造でいずれかの内容で, 設定, 目的, 展開, 結末の構造が認められた４歳児群でもぞうさんのス トーリーではすべての構造が認められた，また，ぞう さんのストーリーの再生のみ, 内容の順番の逆転が 4 歳児で 29 例中 5 例 $(17.2 \%), 5$ 歳児で 23 例中 5 例 (21.7\%)，6歳児で 22 例中 1 例（5\%）あった。なお, 内容の順番が正しい発話例と内容の順番が逆転した発

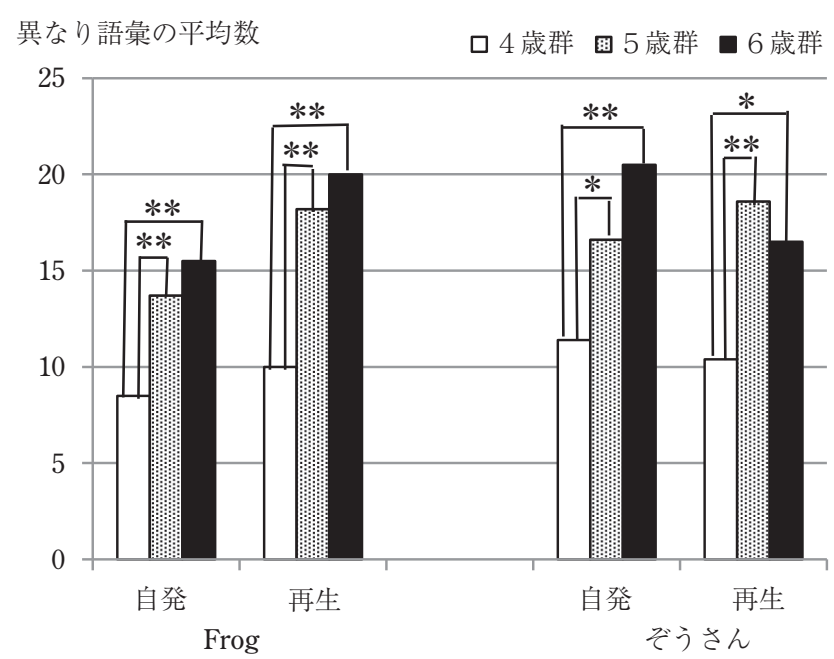

図 7 年齢別の各材料, 各課題の異なり語彙数の平均 分散分析にてそれぞれの課題における年齢群間の有意差を $\mathrm{p}<.01$ を** $\mathrm{p}<.05$ を*で示した。

表 2 ぞうさんのストーリーの内容

\begin{tabular}{|c|c|c|c|c|c|c|c|}
\hline \multirow{2}{*}{ 構造 } & \multirow{2}{*}{ ぞうさんのストーリーの内容 } & \multicolumn{3}{|c|}{ 自発 } & \multicolumn{3}{|c|}{ 再生 } \\
\hline & & 4 歳 & 5 歳 & 6 歳 & 4 歳 & 5 歳 & 6 歳 \\
\hline \multirow{4}{*}{ 設定 } & (1)道路に車が走っている & & & $\bigcirc$ & & $\bigcirc$ & \\
\hline & (2)小さな象が道路にやってきた & & & & & & \\
\hline & (3)象が道路を渡ろうとした & & $\bigcirc$ & () & & & \\
\hline & (4)車にぶつかった & (2) & () & () & () & $\bigcirc$ & () \\
\hline \multirow{2}{*}{ 目的 } & (5)鼻と足にけがをした & (2) & () & O & & $\bigcirc$ & (2) \\
\hline & (6)血が出ている & $\bigcirc$ & & & $\bigcirc$ & & \\
\hline
\end{tabular}

(7)男の子が事故を目撃した

(8)男の子が救急車を呼ぶ

(9) 119 番に電話をした

展開 (10)救急車がきた

(11)象を病院に連れて行った

(12)看護師さんが鼻に包帯を巻いてくれた

13象のけががなおった

(14)お母さ象が探しにきた

(15)お母さと一緒になった

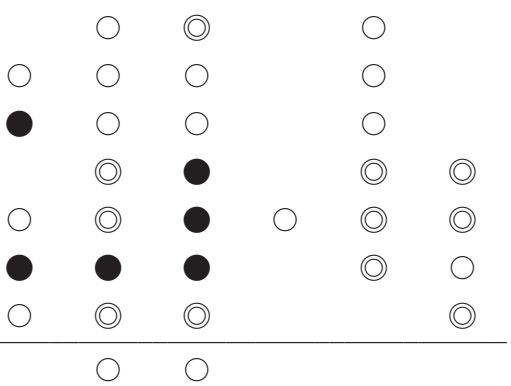

結末

(16)家は木の下にある

(17)家に帰つた

(18)扮母さんが車に気を付けるように言った

()

$50 \%$ 以上出現した内容を（， 30\%以上出現した内容

対象児の $75 \%$ 以上出現した内容 を○で示した。 
話例を付録 4 にまとめた.

ストーリーの内容は産出される語彙との関連性が示 され，異なり語彙数とストーリーの内容数は，いずれ の課題，いずれの材料でもと有意な相関が認められた (Frog の自発話課題で $r=0.80$, 再生課題 $r=0.94$, ぞ うさんの自発話課題で $r=0.67$, 再生課題で $r=0.93)$. また, 異なり語彙数の課題と材料別の年齢群間の比較 では 4 歳群で有意に少ないことが示された（図 7).

\section{考察}

本研究では典型発達児のナラテイブの研究において 材料 (Frog とぞうさん)の違いと課題 (自発話と再生) の違いによるストーリーの語りの発達について検討し た，絵を見てストーリーを語ることは，描写された絵 から言語・非言語情報に基づいた文の構成に関連する メッセージレベルの表象を行う推論過程が含まれる. 本研究の自発話の手続きに打いては最初に 10 枚の絵 を見せ，その後に1枚ずつの自発話を引き出すように した，子どもが全体の流れから必要な情報を絵から取 り出し, 場面の関連をつかみ, 全体を統合して語りの 構造として絵からの情報をまとめ, もっている言語で 特定の視点から言語化する過程が必要である。すなわ ちナラティブには対人関係機能や検査課題の理解（動 機付けなど), 言語能力 (言語の形式的側面), 認知的 側面を基盤として個々人の体験から描写された絵から 言語・非言語情報を取り出してメッセージレベルの表 象を行う必要がある。さらに各部分の詳細で明確な処 理をしながら前後の絵から何が重要であるかを推論 し, 次に来る情報を予測し, 前の情報を対照させなが ら必要な情報を取捨選択しなければならない。そして 最後に物語構造として情報をまとめ, 全体を統合する 複雑な一連の情報処理過程である ${ }^{18)}$.

内田 ${ }^{19)}$ は，幼児の語りに扔いて 2 こまの系列絵の 叙述から子どもの物語ることの発達について詳細に分 析している. 2 歳代では絵に制約を受けて列記的表現 となり，3歳代では絵の内容を越えて想像したことを 盛り込むことができるようになると報告している，3 歳後半〜 4 歳前半になると出来事を組み合わせてこと ばで表現することができ，4歳後半〜 5 歳前半にかけ て事件を盛り込んだ物語構造の形式が可能になり，5 歳後半に物語技法を用いて語ることができ, 質的転換 のときであるとしている，内田は，幼児期に扔いても かなりの説明技能をもち, 原因が結果に先行するもの であるという因果の理解は早くから可能であると述べ ている.しかし, 結果が先にあり原因が後に来るといっ
た時間順序が逆になるように言語化することは難し く, 5 歳前半と 5 歳後半の間で質的転換の規定因の一 つとしている。 なお，内田の研究では男の子が石につ まずいて転んで泣いたという事象の 2 枚の絵を呈示 し，「まさおちゃんが石につまずいてころんだ」と表 現することは容易であるが逆向呈示条件での「まさお ちゃんは泣いている，石につまずいて転んだから」と 表現できるか否か, およびどのように表現するかを検 討している.

Slobin ${ }^{20)}$ は, Frogのストーリーを用いて 5 歳児と 9 歳児を比較し，5歳児に扔けるストーリーの構造が 未発達であることを示唆している. 5 歳児は設定場面, 内的状況, 継続的な目標志向性, 最後を最初の状況と の関連で述べ，全体としては話が飛んで統合されてい ない.しかし，9歳児ではより精緻な設定場面や時間 的推移, 時間的な後戻り, 出来事の動機や原因につい て語れるようになり，談話文脈のなかで語り手の視点 などを投影し多彩な役割を担うようになるといった変 化があると述べている，両研究から子どもの物語技法 の発達について同じ方向性をもっていることが示唆さ れている. しかし, その発達の年齢は異なり, 材料の 長さや内容(生活のなかで経験してきた事柄であるか, 事物やことばの知識をもっているかどうか, ストー リーの因果的・時間的関係など内容と構造の複雑さ) によって影響されると考えられる。すすおち, 物語構 造や内容は年齢や個々人の言語や認知の発達全般との 関係が大きいといえる.

本研究では材料の違いにおいて 4 歳児の Frog がぞ うさんよりもストーリーの内容, 構造ともに量, 質と もに少ない傾向にあった４歳児は登場するキャラク ターへの親密度や体験からの情報や語彙の難しさがあ り, 細部の絵の描写の解釈が難しいため, 絵からの情 報の取出しや言語化する際のメッセージレベルの表象 が難しいと考えられた。 5 歳児では 4 歳児同様, Frog がぞうさんよりも自発話が少ない傾向があったが，6 歳児では再生において Frog がぞうさんよりも自立語 が多く産出された，年齢の増加とともに自立語数が増 加し, 最も詳細に語ることのできる 6 歳児でのぞうさ んの自発話課題と Frog の再生課題の自立語数となっ た. 6 歳児の再生課題でFrogがぞうさんよりも自立 語数が多くなったことは，本来のストーリーの構造に 抒いてFrogがぞうさんよりも情報処理が複雑で，か つ情報内容が多く，そのため多くの語彙が必要である と考えられた。

一方, ナラティブの年齢的な発達において年齢の増 
加によって発達していくことを研究した文献は多

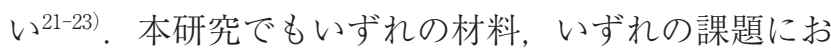
いても年齢の増加とともに語りの長さの指標である自 立語数が増加し，内容についても徐々に充足されて いった４歳児においては十分なストーリーの内容を 再生し, 物語ることは難しいことが示された５歳以 上では徐々に材料による差異が明確になり，6歳では 有意に材料間の差異があった。したがって，本来のス トーリー内容の知識, 内容量や構造の特徵によって, 材料によるストーリーの複雑さが決定し, 言語・認知・ 社会性の発達に伴い, 語りの材料が本来もっている詳 細な内容をもつ構造を産出することが可能となること が示された，年齢によってナラテイブが発達すること は示されたが，各年齢群ともに個人差が大きく，平均 から外れる児やナラティブの産出が困難である児に対 して，さらなる評価が必要であると考えられた，描か れた絵のストーリーを物語ることは, 細部の絵の描写 の解釈が難しい内容において出現率が低く, 絵の描写 といった視覚的情報処理もストーリー内容の記憶に関 与し, ナラティブに反映する要素であると考えられた.

また，興味深いことにぞうさんの物語でのみ再生に おいて 4 歳児，5歳児で内容の順番の逆転が多く認め られた，親密度の高い日常的な内容ではみずからの経 験も混じり，時間空間的な記憶とも関連し，混乱する ことが順番の誤りの原因と考えられ，物語の材料にお ける内容の親密度は重要な要素であり, 再生課題にお いては記憶や言語学習の発達との関連性が高いことが 示唆された。

Alamillo ら ${ }^{24)} は$ “Tom and Jerry” のアニメーショ ンを材料にしたナラティブについて 6 歳児と 10 歳児 を比較し，6歳児では発話の長さや内容において十分 ではなく, 他の文献同様に本格的なナラティブは学童 期になってからであると述べている，学童期には時間 的, 因果的関係の表現の使用が可能となり, ナラティ ブにおいてたくさんの情報を産出できるようになって いく25,26). しかしながら, 本研究の結果から長さが短 く高頻度でよく知っている内容で喚語が易しい内容で あれば, 5 歳児以上の典型発達児ではある程度の発話 の長さと内容のあるナラティブを産出できるようにな ると考えられた。

近年増加している ASD のナラティブの研究では標 準化された表出面の検査において良好な成績を示して もナラティブの産出では物語技法や因果関係の叙述, ときには統語レベルでの貧困さがあり，質量ともに障 害があることが報告されている10)。本研究では談話レ
ベルの評価として 10 枚の系列絵による $2 つ の$ 異なっ た材料を用いた自発話および再生課題での標準的長さ と内容を示すことができた、今後，わが国における言 語障害および社会性の障害のある ASD 览の早期発見 のツールとして有用であると考えられた。

\section{結論}

ナラティブの能力は学齢期の教科学習能力との関連 性があるとされている27)。 また ASD 览などのコミュ ニケーションの発達に障害のある览では, 標準化され た検査では明らかにならない場合があるが，談話レべ ルの評価によって言語能力ばかりではなく，記憶や推 論および視覚的認知といった認知面, 社会性や動機づ けなどの情緒面も含み，多側面の情報処理が必要とさ れるため, 障害の本質を明確にすることが可能である. ナラティブの評価は重要であるが, これまで典型発達 児のナラティブの発達において明確な基準がなく、さ らにわが国では語用論からのアプローチは皆無であっ た. 本研究では典型発達児のナラティブの発達の標準 的な結果を示すことができた，すなわち材料や課題に よらず 4 歳児と 5 歳以上の発話の長さや内容は有意に 異なることや個々の子どものナラティブの産出能力 は, 課題や材料によらず, ストーリーの長さや語彙数, 統語において同一個人内での高い相関を示すことを証 明した。ストーリーの構造や内容からその子どもの認 知・言語・社会的能力の総合的能力が評価できるとい うことを示した，さらに，個々の子どものナラティブ の問題を質的に検討することによってその問題が社会 性にあるのか, 認知面にあるのか, 言語面の語彙, 統 語，意味，語用にあるのかを検討することも可能であ る.ナラティブの能力を評価し, その後の発達的な問 題への介入計画に打いて本研究は, 子どものナラティ ブの発達について一つの基準を示すことができた.

本研究は平成 22 年度川崎医療福祉大学医療福祉研究費助成 の研究成果である. 平成 22 年 7 月 21 日に研究D コースの研究 課題『語用論の発達: 子どものナラテイブの構造と形式につい て』として承認された。 これによる利益相反はない．

また, 本研究は平成 23 年 12 月 7 日に川崎医療福祉大学倫理 委員会（承認番号 294）によって承認された。

\section{文献}

1) Brown R: A First Language: The Early Stages, Harvard University Press, Cambridge, MA, 1973.

2) Slobin DI: Crosslinguistic evidence for the languagemaking capacity. The Crosslinguistic Study of Language Acquisition (edited by Slobin DI), Lawrence Erlbaum 
Associates Publishers, Hillsdale, NJ, pp 1157-1256, 1985.

3) Ochs EL, Smith R and Taylor C: Dinner narratives as detective stories. Cultur Dyn, 2: 238-257, 1989.

4) Mayer M: Frog, Where Are You? Dial Press, New York, 1969.

5) Miles S and Chapman RS: Narrative content as described by individuals with Down syndrome and typically developing children. J Speech Lang Hear Res, 45: 175189, 2002

6) Norbury CF and Bishop DVM: Narrative skills of children with communication impairments. Int J Lang Commun Disord, 38: 287-313, 2003.

7) Reilly J, Losh M, Bellugi U, et al: "Frog, where are you?" Narratives in children with specific language impairment, early focal brain injury, and Williams syndrome. Brain Lang, 88: 229-247, 2004.

8) Polanyi L: Telling the American Story: A Structural and Cultural Analysis of Conversational Storytelling, MIT Press, Cambridge, MA, pp 15-30, 1989.

9) Gabig CS: Verbal working memory and story retelling in school-age children with Autism. Lang Speech Hear Serv Sch, 39: 498-511, 2008.

10) Manolitsi $M$ and Botting $N$ : Language abilities in children with autism and language impairment: using narrative as a additional source of clinical information. Child Lang Teach Ther, 27 (1): 39-55, 2011.

11）茂呂雄二：児童の文章産出一短作文における文脈形成分析 の試み。教育心理学研究, 30 (1) : 29-36, 1982.

12）西川由紀子：幼児の物語産出における「語り」の様式. 発 達心理学研究, 6:124-133, 1995.

13）斉藤佐和子：健常幼児の格助詞と態の表出一構文検査（斉 藤私案）を使用して一。音声言語医学，43：173-181, 2002.

14) Shank RC and Abelson R: Scripts, Plans, Goals and Understanding, Lawrence Erlbaum Associates, Hillsdale, NJ, 1977.

15）上野一彦, 撫尾知信, 飯長喜一郎：絵画語い発達検査, 日 本文化科学社, 東京, 2008 .

16）綿巻 徹:ダウン症児の言語発達における共通性と個人差, 風間書房, 東京, 259-281 頁, 1999 .

17）小椋たみ子, 中 則夫, 山下由紀恵, 他：日本語獲得児と 文法の発達一CLAN プログラムによる分析. 神戸大学発
達科学部研究紀要, 4 (2)：31-57, 1997.

18) Joanette $Y$, Goulet $P$, Ska B, et al: Informative content of narrative discourse in right-brain-damaged right-handers. Brain Lang, 29: 81-105, 1986.

19）内田伸子：幼児における事象の因果統合と産出. 教育心理 学研究, 33 (2) : 124-134, 1985.

20) Slobin DI: The development from child speaker to native speaker. Cultural Psychology: Essays on Comparative Human Development (edited by Stigler JW, Herdt G and Shweder RA), Cambridge University Press, Cambridge, England, pp 233-256, 1990.

21) Fitzgerald J, Spiegel DL and Webb TB: Development of children's knowledge of story structure and content. J Educ Res, 79 (2): 101-108, 1985.

22) Hudson JA and Shapiro LR: From knowing to telling: The development of children's scripts, stories, and personal narratives. Developing Narrative Structure (edited by McCabe A and Peterson C), Lawrence Erlbaum Associates, Hillsdale, NJ, pp 89-136, 1991.

23) Coletta JM, Pelling C and Guidetti M: Age-related changes in co-speech gesture and narrative: Evidence from French children and adults. Speech Commun, 52: 565-576, 2010.

24) Alamillo AR, Coletta JM and Guidetti M: Gesture and language in narratives and explanations: the effects of age and communicative activity on late multimodal discourse development. J Child Lang, 40: 511-538, 2013.

25) Hickman $M$ and Hendrics $H$ : Cohesion and anaphora in children's narratives: A comparison of English, French, German and Mandarin Chinese. J Child Lang, 26: 419452, 1999.

26) Berman RA and Verhoeven L: Developing text-production abilities across language, genre, and modality. Writ Lang Lit, 5: 1-44, 2002.

27) Boudreau D: Narrative abilities. Advances in research and implications for clinical practice. Top Lang Disord, 28 (2): 99-114, 2008.

\author{
別刷請求先：干701-0193 岡山県倉敷市松島 288 \\ 川崎医療福祉大学医療技術学部 \\ 感覚矯正学科言語聴覚専攻 \\ 小坂美鶴
}




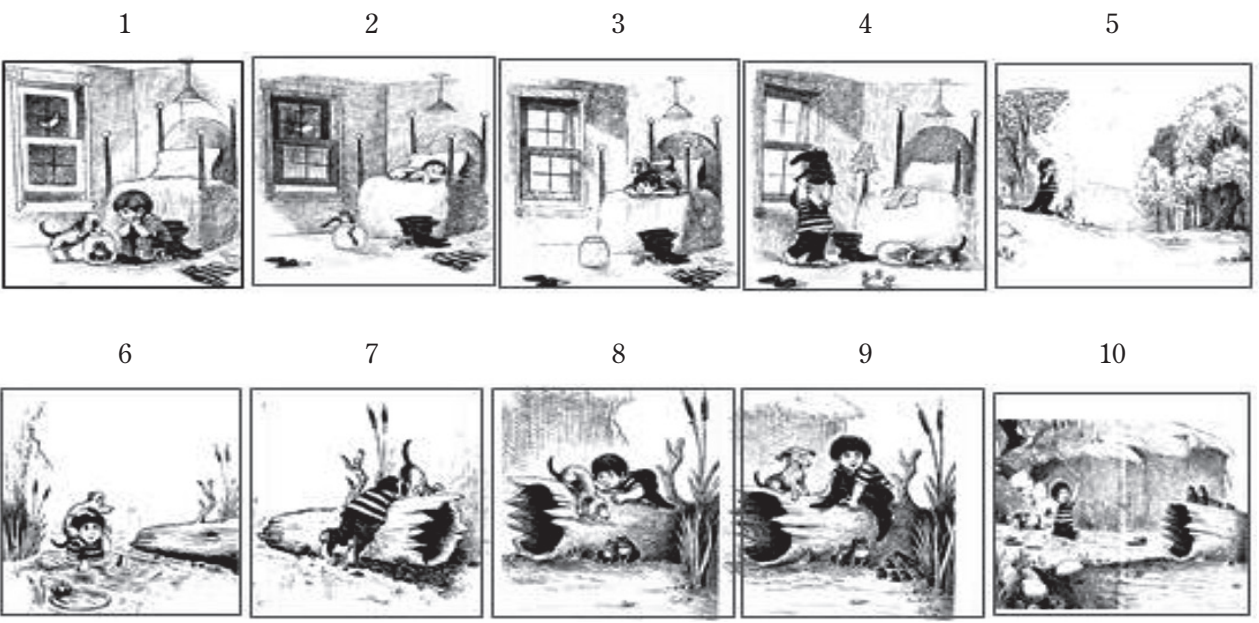

"Frog, Where Are You?"

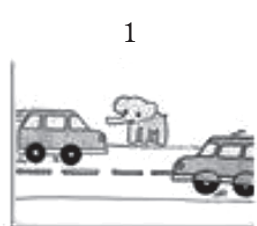

6
2

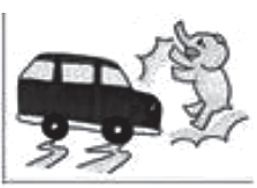

7
3

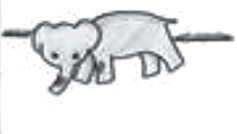

8
4

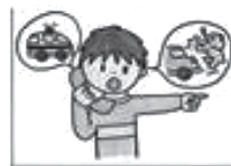

9

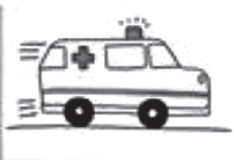

10
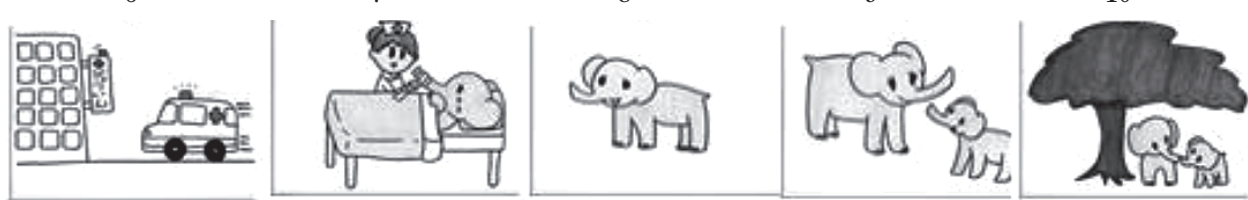

“ぞうさん故郷に帰る”

付録 1 語りの材料

設定 (1) 1-1 蛙をつかまえてきた

(2) 1-2 蛙を犬と一緒に見ている

(3) $2-1$ ベッドで寝た

(4) 2-2 その間に蛙が逃げた

(5) 3-1 朝起きると

(6) 3-2 蛙がいない

目的 (7) 4-1 家の中を探した

(8) 4-2 長靴や瓶の中を探した

(9) 4-3 蛙がいない

(10) 5-1 外に出た

(11) 5-2 森に向かって叫んだ

展開 (12) 6-1 池に落ちた

(13) 6-2 木の陰から蛙の声が聞こえた

(14) 7 木の陰をのぞいてみた

(15) 8 二匹の蛙がいた

(16) 9 たくさんの子どもの蛙が出てきた

結末 (17) 10-1一匹蛙をもらった

(18) 10-2 蛙にバイバイして州った

"Frog, Where Are You?"

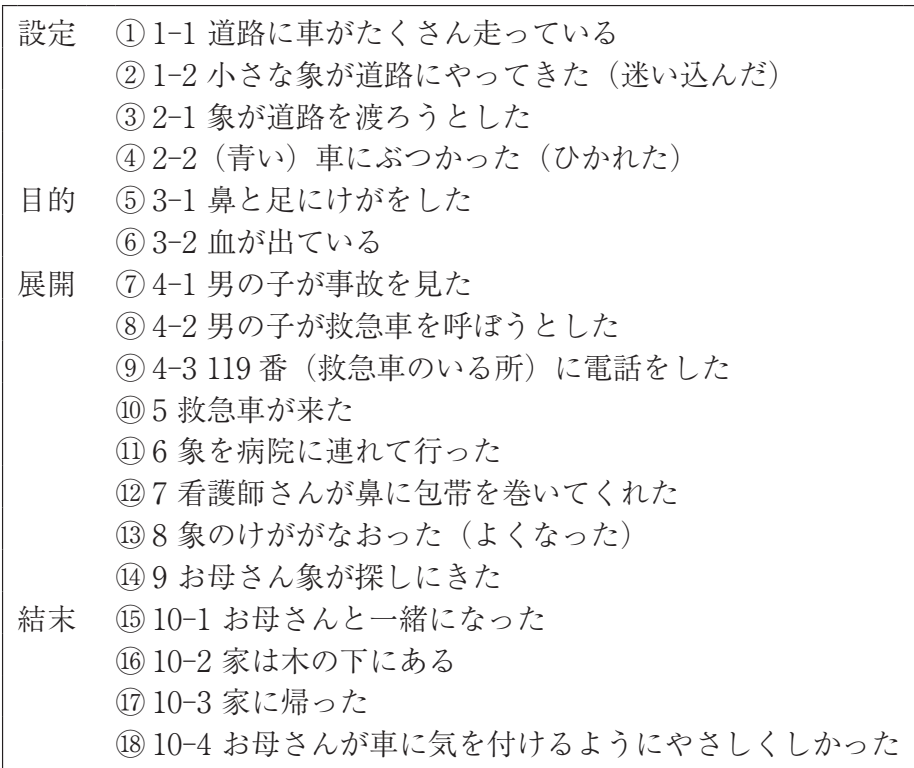
“ぞうさん故郷に帰る”

付録 2 絵に合わせたストーリーの内容と物語構造 
付録 3 実際のデータ分析

Frog の自発話課題の転記データ (CA6:03)

「これは まず かえる みよって こう 男の子が すわりよって 夜に なって 次は パジャマを着て 抆とた ら かえるが にげようて 朝に なると 抽んようくなって また 朝 着替えて 長靴 はいて 外に出て かえ

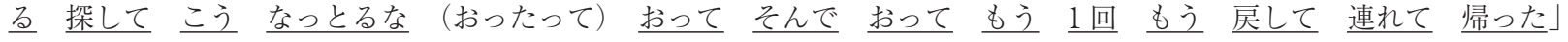

（1）自立語ごとに分け，自立語数を数える（アンダーラインで示す）

*括弧内は言い直しのため分析から除く

（2）付属数を算出する（太文字で示す）

*方言は標準語に言い換えた形式にして文法要素を求める

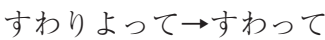

ねとったらーねてたら

にげようてーにげて

おらんようくなって $\rightarrow$ おくなって

（3）内容の分析（18 個の基準となる内容の番号のうち出現した内容 $)$

(2)蛙を犬と一緒に見ている

(3)ベッドで寝た

(4)その間に蛙が逃げた

(5)朝起きると

(6)蛙がいない

(10)外に出た

(15)二匹の蛙がいた

(17)一匹蛙をもらった

18蛙にばいばいして帰った

付録 4 内容の順番が正しい発話例と逆転した発話例

(1) 内容が順番通りのナラティブの例

6 歳 3 カ月：(1)最初に道路がいっぱいあって, タクシーとか車がびゅんびゅん通って, (3)どうたんがな, 渡りようたら, (4)車がぼーんってぶつかって, 8)男の子が病院に(9) 119 番呼んで, (12)でうさんを優しいかんごくさんに包帯巻いて, (13)すっ かりよくなって治って, (14)扔ささん゙来て, (17)帰った.

4 歳 5 カ月:(3)渡ろうとした. (5)がした. 8)救急車を男の子が呼んだ。(12)包帯を巻いてくれた。お医者さんが. (13)治った. (14)扮母さんが扮迎えに来てくれた。18いっぱいおるところにはいかないって言ってた。

(2) 内容の順番が逆転したナラティブの例

5 歳 6 カ月：ぞうの括。(5)ぞうがけがやった。(10)警察のあれ連れてきた。(14)拇さんが探しに来た。(12)かんごくかん治 してくれた。(8)男の子が警察呼んだ。(17)ぞうなあれ連れてきてくれた。

4 歳 4 力月：(4)車にぶつかった。(10)それで救急車に運ばれた。(15)ぞうさんがお母さんに会った。 (16)それから木の上に(17) 母さんと一緒に休んだ。(8)男が救急車を運ばれましたって言った。

(発話の文 (接) に付けた数字は付録 2 の発話の内容番号) 